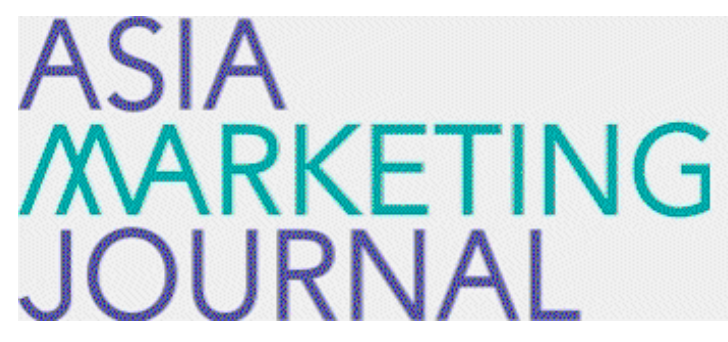

ASIA MARKETING JOURNAL

Volume 14 | Issue 1

Article 8

4-30-2012

\title{
The Role of Perceived Quality in New Product Adoption Process in China
}

Ji Yoon Kim

Xina Yuan

Follow this and additional works at: https://amj.kma.re.kr/journal

Part of the Marketing Commons

\section{Recommended Citation}

Kim, Ji Yoon and Yuan, Xina (2012) "The Role of Perceived Quality in New Product Adoption Process in China," Asia Marketing Journal: Vol. 14 : Iss. 1 , Article 8.

Available at: https://doi.org/10.53728/2765-6500.1476

This Article is brought to you for free and open access by Asia Marketing Journal. It has been accepted for inclusion in Asia Marketing Journal by an authorized editor of Asia Marketing Journal. 


\title{
The Role of Perceived Quality in New Product Adoption Process in China
}

\author{
Kim, Ji Yoon* \\ Yuan, Xina**
}

\begin{abstract}
This study investigate the role of consumer's perception of quality in new technology adoption process in China which is given little attention in the field of Information System and Communication Technology. Here, we developed a simple model in the level of consumer perception by exploring the antecedent of perceived quality. Three factors are introduced as determinants of perceived quality: perceived usefulness, perceived risk and trialability. An empirical study is conducted with analysis of the adoption mechanism of a new innovative product. Data analysis results support some of our proposed hypotheses. It indicates that perceived quality is positively related to the adoption intention and fully mediates the relationship between triablility and purchase intention. And we conclude that a product's perceived quality plays an important role in adoption intention. And what makes Chinese customers perceive product's quality good is a trialability of a product. This suggests that when market managers plan to launch products in China, they need to craft an effective strategy based on the market system of the consumer especially understanding the consumers' critical factor for adopting a new product. Chinese are more interested to purchase a product with free trial and free experiential period, therefore, suggesting an advertisement highlighting the trialability of a product is possible in China.
\end{abstract}

Key words: Perceived Quality, New Product Adoption, TAM, China, Trialability

\section{Introduction}

As new innovative product shift from being

a luxury to a commodity, the mobile phone and other innovative devices have been increasingly adopted by ordinary Chinese consumers. For example, the development of smart phone is reaching a critical stage in China. According to iResearch(2011) reports, along with a cost

* Ph.D., Korea University Business School(jyoonk77@naver.com)

** Assistant Professor, School of Management, Xiamen University(zinayuan@xmu.edu,cn), Corresponding author 
reduction, the smart phone industry in China has recently started to increase. It is estimated that there could be an additional 100 million Chinese people logging on to the internet via mobile devices from the year 2011 to 2012 . And over one-third of digital addicted customers and mobile mavens replace their mobile phones every 12 months or less (Lin et al. 2011). Other devices such as mobile internet service, computers are also increasing gradually. Along with the development of new technology market and fierce competition in a market, companies try to seek new opportunities by investing on new technology development and launching innovative new products (Eng and Quaia 2009). For the past two decades, digital revolution has lead to a huge growth of the new technology products market and a huge number of new products have been introduced in the market, but not all could be successful since only a few products could meet the consumers needs in different market environments. Thus, understanding the new technology adoption process is an important for a form to launch a new product successfully.

The adoption of new technology product has been studied with different theoretical frameworks such as the diffusion of innovation theory (Rogers 2003) and the theory of reasoned action (Fishbein and Ajzen 1975). In addition, technology acceptance model (Davis 1989) is known as one of the most common models to explain technology acceptance (Pagani 2004: Nysveen et al. 2005). TAM suggests that two beliefs (perceived ease of use and perceived usefulness) are the predictor of the attitudinal component of customers' adoption intention(Davis 1989). Bagozzi (2007) states that based on TAM there are more than 700 citations of the variables in the model.

Despite the large citation of of TAM, one of the shortcomings of the TAM is that it does not consider customers' emotions as a predictor of both consumers' attitude toward the act of using the new product and their actual behavior (Bagozzi 2007). Indeed, consumer behavior theory proves that utilitarian motives are not sufficient to describe consumers' behavior toward a product (Childers et al. 2001). Therefore, in this study we try to develop a new adoption model from the perspective of customers' perception of a product since customer behavior is always influenced by the customers' primary attitude toward products.

This paper is focused on establishing a simple conceptual model for examining perceived quality toward new products. Perceived quality of a brand, here is a consumer's attitude toward a specific brand, which influences the judgment made with the evoked set that leads consumers to recall the brand (Aker and Keller 1990). In addition, several firms have found that perception of good quality is an essential factor for achieving competitive advantage (Aaker 1991). Therefore, just making consumers think that innovative products that seem to have a good 
quality will enhance the attitude toward the product which makes them to purchase. Holbrook and Corfman (1985) argue that quality acts as a relatively global value judgment. However, little work is done to investigate the perceived quality of a product on purchase intention. Accordingly, we will consider the antecedents of perceived quality such as perceived usefulness, perceived risk and trial ability in new product adoption process.

Moreover, many researchers propose that additional variables need to be used to predict user's behavior intention. Liu and $\mathrm{Li}$ (2009) indicate that there are other predictors of adoption of new technology in China such as relative advantage, perceived compatibility and perceived complexity, perceived observability and perceived enjoyment. Lu et al. (2007) confirm the validity of TAM by investigating the wireless mobile data of China.

This is aimed at developing a simple model of new product adoption for exploring the factor influencing perceived quality in China. An empirical study is conducted for the adoption of smart phone (iPhone) in 2009 with 173 samples from Chinese students. Results from structural equation model (SEM) analysis illustrate the ability of the model to interpret the role of perceived quality in the new technology adoption. For the survival of new product development in the market, analysis of strategy and the market situation including infrastructure, proper product launch timing, and a clear under- standing of consumers' characteristics and purchase behavior based on the market situation are essential.

\section{Theoretical Background}

\subsection{New Product Adoption}

Rogers (1983) introduces some factors for adopting new technology products, which is adopted by Davis (1989) to develop the Technology Acceptance Model (TAM) in the perspective of product users (Moore and Benbasat 1991: Tung et al., 2008). The main focus of this research is the consumers' perception of making use of the innovations rather than perception of the innovation as it is. Extant research on innovation adoption literature mainly suggests the primary attributes which is intrinsic to the innovation, are independent of the perception of their potential adopters. However, the behavior of individuals is predicted by how they perceived these primary attributes of a product. Because different adopters might perceive primary characteristic in different ways, their consequent behaviors might be different depending on the perception of the innovation itself. This is the original problem of using primary characteristics as research variables (Moore and Benbasat 1991). In the TAM, it only considers two factors of Rogers proposed 
"Perceived usefulness and Ease of use".

Perceived usefulness is a similar concept with "relative advantage" in which Rogers, expanded technology innovation adoption factors from users' perspective (Moore and Benbasat, 1991). Perceived usefulness is defined as the degree to which individual perceives that using a particular product would enhance his job performance (Davis 1989). Moreover it is an innovation characteristic, which is directly related to potential customers' decision making process as it is a measure of how innovative products are positively perceived compared to existing products (Davis 1989, 1993). This origin is from the definition of the word useful: "capable of being used advantageously." A number of study demonstrate that a product's perceived usefulness has the strongest direct impact on consumers' adoption intention among other various innovation product attributes (Adams et al. 1992: Davis 1989) and when an individual perceives a product as useful, then there is a positive use-performance relationship. "Ease of use" is a relative concept with "perceived risk" of Rogers so that potential customers will be less likely to adopt them if new technology products are extremely complicated and difficult to use. However, perceived risk is a broader concept. 'Risk' means 'uncertainty', which includes the risk from the learning cost and observability. If a new product has a risk regarding its function, time or any other related to it, it would be a barrier for a customer to adopt it. In this study we define perceived risk as a consumer's belief about the potentially uncertain negative outcomes from the adoption of innovative product. Since the concept of perceived risk has appeared in the marketing literature, various types of risk have been identified (Zikmund and Scott 1973). There are six types of perceived risk that have been identified: financial, performance, social, physical, privacy, and timeloss (Roselius 1971). However, the dimensions of perceived risk may vary according to the product (or service) class (Featherman and Pavlou, 2003). Moreover, it is important to dominate consumers' perception of economical and physical value of new technology products (Jacoby and Kaplan 1972) since it may influence consumers decision making on whether the innovative product becomes a new standard or only short-lived (Rogers 1995).

Trialability is also an important factor in new product adoption. Trialability is referred to as divisibility which indicates the degree to which an innovation can be tried on a limited basis before purchase(Rogers 1995). Trialability allows individuals to try ahead and buy a product: if individuals try new product which seems to satisfy individuals' needs and wants, then they are likely to buy it: if not, they will not probably buy it. New product affords individual customers an opportunity to try this new innovation. To the extent that trialability is perceived to be available for the new product, there is probably a greater likelihood of con- 
sumers' belief on the desirability of this new product. Innovative product's trialability should therefore be positively related to individual customers' attitude toward the product and intention to adopt it.

\subsection{Perceived Quality}

Perceived quality is defined as "subjective quality" which relates to an individual purchaser's perception of its physical attributes and functionality (Kotler 1994). Zeithaml (1988) summarizes its characteristics from a comprehensive perspective. She argues that perceived quality is different from objective quality, and is more closed to upper level, abstract concepts rather than specific attributes of a product. Moreover, Holbrook and Corfman (1985) indicate that subjective quality is more humanistic than objective quality. Perceived quality is always based on consumers' behavioral judgments on various attribute sets. And Aaker and Keller (1990) state that the perceived quality of a brand is a consumer's attitude toward a specific brand, which influence the judgment made with the evoked set that makes consumers recall of the brand. A good quality reputation is usually based on achieving a high level of quality.

Just delivering quality, however, is not enough. Several firms (e.g., Schlitz Beer, which had a short-lived quality problem in the 1970s: Audi, which had a "sudden acceleration problem") have found that perceptions of quality must be essential for a firm to realize a competitive advantage (Aaker 1991). Therefore, in consumer's adoption behavior, how to perceive the quality of a new product is an important determinant of its success. Clark et al. (2009) use a panel data to investigate the effect of advertising on brand awareness and consumer's perceived quality. They find that advertising has consistently a significant positive effect on brand awareness but no significant effect on perceived quality. Ladhari et al. (2011) confirm that perceived service quality, emotional satisfaction and image are key drivers of fostering loyalty and recommendation

\section{Research Framework and Hypotheses}

Perceived quality is the consumers' judgment about a product's/service's overall evaluation (Zeithaml 1987). There are some contradictory studies on impact of perceived quality toward purchase intention. Some studies show perceived quality also gives impact to purchase intention through satisfaction or other variables (Cronin and Taylor 1992, Sweeney et al. 1999) while other studies show perceived quality is positively related to purchase intention directly (Boulding et al. 1993, Parasuraman et al. 1996). And there is a positive effect between quality and 
customer loyalty intentions which leads to continuous purchase intention (Gustafsson et al. 2005). Boisvert and Ashill (2011) show that quality has a positive effect on consumer's behavioral intentions. In the meantime, Park and Kim (2002) show products with high quality perception by consumers give a higher purchase intention than those with lower quality perception. Therefore, we propose our first hypotheses:

\section{H1: Perceived Quality positively relates to the} new product adoption intention in China.

Previous research on innovation diffusion has considered primary factors affecting product adoption. In our study, we propose that Perceived usefulness, Perceived risk and trialablility are three important impact factors of the new technology adoption process. Perceived usefulness has been considered as an important factor in product adoption by the users (Dubey \& Wu 2002: Fishman \& Rob 2002). When specific products or services are highly useful, new products are quickly accepted in the market. Koufteros et al. (2002) show that making the best use of computer gives positive impact to product quality. And, perceived usefulness has a positive effect on intention to adopt wireless internet service via mobile technology ( $\mathrm{Lu}$ et al. 2005). Yang et al. (2005) suggest that usefulness of content of the web portal is one of the factors of proposed quality dimension which affect overall service quality. Therefore, we suggest the following hypotheses:

\section{H2: Perceived usefulness positively relates to the perceived quality of a new product in China.}

Bauer (1960) introduced the concept of perceived risk into consumer behavior research field. Consumers' behavior can trigger unpredictable outcomes and some of them include undesirable risks. Perceived risks are subjective risks which contrast objective risks. They also include psychological risks perceived by consumers when selecting brands, stores, and purchasing methods to achieve specific purchase objectives. These perceived risks by consumers have been measured in various ways (Roselius 1971). Chang and Chen (2008) show that perceived risk have an effect on consumer's purchase intention through other variables such as trust in online store research. Park (1999) demonstrates relationship between perceived risk and perceived service quality in hotel service, meaning that perceived risks on service create negative perception on the quality. We give our third hypotheses:

\section{H3: Perceived risk negatively relates to the perceived quality of a new product in China.}

Trialability (or divisibility) here is defined as a users' using of part of the product before 
making decision for purchase (Rogers 1995). Any product or brand, to a greater or lesser extent, is new to consumers before consumption and thus it is necessary to have a certain degree of trialability. In this study, trialability of a product is defined as the extent to which the product can be used or tried on a limited basis before purchase. Chau and Ho (2008) shows high trialability on Internet increases brand equity by reducing information gathering costs on products. There is a positive relationship between product trials and consumer evaluation of co-branded products and purchase intention (Washburn et al. 2000). Chau and Ho (2008) suggest that trialability has a positive effect on the consumer-based service brand equity by mediating the perceived benefit, which includes perceived quality. Ho, Newell, and Walker (2005) indicate that the trialability is the most important factor for affecting the building quality.

H4: Trialability positively relates to the perceived quality of a new product in China.
Therefore, our proposed model is shown as Figure 1.

\section{Research Methodology}

\subsection{Data and Measures}

To test our hypotheses, data was gathered from questionnaires sent to college students in China. The smartphone (iPhone) was selected as the new technology product. The data was gathered in 2009, before the recent smartphone boom ( $88 \%$ responses indicate that smartphone is the new technology product). When Apple Company just launched the iPhone in China in 2009, people were not familiar with it because it was new at that time. Also, respondents were limited to those who had never used iPad or other smartphone devices before, and not familiar with the product. Over one month period, 173 surveys were completed from Chinese students.

〈Figure 1〉 Conceptual Model

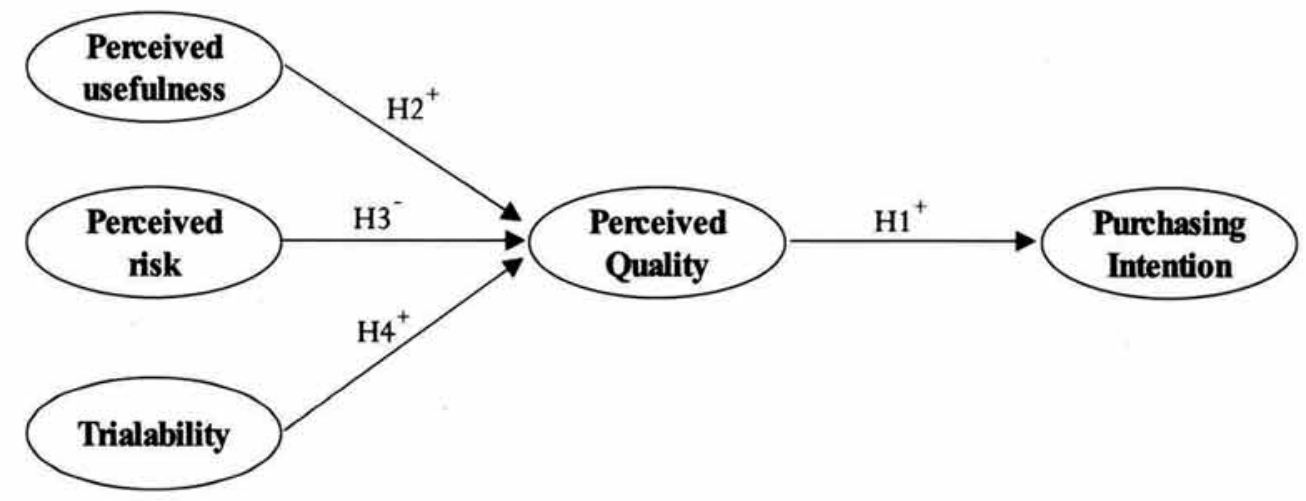


The questionnaire was conducted with sevenpoint scales. We provided pictures of the product (smartphone) and described its function in the questionnaire. Participants were asked to complete questionnaire drawn from previous research (Goldsmith and Hofacker 1991; Karahanna et al. 1999: Jacoby and Kaplan 1972) indicating how do they think about perceived usefulness, perceived risk, trialability, and perceived quality of the product, and how much intention they have about buying the product $(1=$ "not at all", and $7=$ "very").

\subsection{Measurement Assessment}

We conducted SPSS 18.0 and AMOS 18.0 to test the hypothesis. We first assess via principal-axis factoring which completed using an Eigen value of 1.0 and factorings of .50 as cut-off point suggested by Zaichkowsky(1985). Convergent validity of items is assessed using three criteria suggested by Hair et al. (2006) Following are the consequences of the confir- matory factor analysis. First, the reliability of each scales ranged between .773 and .950 , indicating the measures have acceptable reliability regarding their respective constructs, .70 as the cut-off point suggested by Nunnally(1978). Second, the Composite Reliabilities (CR) of each construct is greater than .90 which is above the cut-off value of .70 . Third, Average variance extracted (AVE) of all constructs are all above the threshold levels of .50 thereby demonstrating good internal consistency (Fornell and Larcker 1981). Moreover, AVE shows higher than the squared correlation coefficients between factors, which indicating that each construct is more closely related to its own measures than those of other constructs, an discriminant validity of each construct is confirmed. The results were shown in Table 1.

A series of confirmatory factor analysis (CFA) was used to assess internal consistency and convergent validity. Table 2 summaries the CFA for each construct, which yields an acceptable overall fit to the data $\left(\chi^{2}=301.649\right.$, d.f. $=$

〈Table 1〉 Reliability of Constructs

\begin{tabular}{lcccccccccc}
\hline & \# items & Mean & SD & CR & AVE & PerUse & PerRis & Try & PerQua & PI \\
\hline PerUse & 6 & 4.26 & 1.42 & 0.945 & 0.862 & 0.950 & & & & \\
\hline PerRis & 5 & 4.48 & 1.21 & 0.951 & 0.800 & $.403^{* *}$ & 0.826 & & & \\
\hline Try & 3 & 4.34 & 1.14 & 0.937 & 0.835 & $.342^{* *}$ & $.151^{*}$ & 0.773 & & \\
\hline PerQua & 3 & 4.75 & 1.17 & 0.960 & 0.889 & .147 & -.031 & $.294^{* *}$ & 0.912 & \\
\hline PI & 3 & 3.83 & 1.38 & 0.944 & 0.849 & $.451^{* *}$ & .122 & $.386^{* *}$ & $.216^{* *}$ & 0.856 \\
\hline
\end{tabular}

** Correlation is significant at the 0.01 level (2-tailed)

* Correlation is significant at the 0.05 level (2-tailed)

Coefficient alphas are shown in italics on the diagonal: CR stands for composite reliability and

AVE stands for average variance extracted 
160, $\mathrm{p}=.000: \mathrm{RMR}=.147, \mathrm{GFI}=.850, \mathrm{CFI}=$ .938 , RMSEA $=.072$ ). In addition, all the factors loading are significant and exceed the .50 threshold point. Therefore, the internal consistency of the scales is acceptable for the main hypotheses testing.
We conducted two steps of statistical analysis to assess the threat of common method bias according to the proposed approach of Podsakoff et al. (2003). First, we conducted Harmon's single-factor test. The result of EFA with 20 items revealed six factors that had Eigen

〈Table 2〉 Covergent Validity (First-Order Full CFA)

\begin{tabular}{|c|c|c|}
\hline & Construct & Factor Loading (s.e.) \\
\hline \multirow[t]{6}{*}{ Perceived Usefulness } & $\begin{array}{l}\text { This product would enable me to accomplish tasks more } \\
\text { quickly }\end{array}$ & $0.828(.078)$ \\
\hline & This product would improve my job performance. & $0.887(.081)$ \\
\hline & This product would increase my productivity & $0.931(.077)$ \\
\hline & This product would enhance my effectiveness on the job. & $0.931(.079)$ \\
\hline & This product would make it easier to do my job & $0.900(.080)$ \\
\hline & This product would be useful in my job. & 0.796 \\
\hline \multirow[t]{5}{*}{ Perceived Risk } & I doubt the composition of this product. & $0.519(.121)$ \\
\hline & $\begin{array}{l}\text { My concern is that this product would not function } \\
\text { as expected. }\end{array}$ & $0.797(.146)$ \\
\hline & $\begin{array}{l}\text { Im concerned this product would not meet the quality } \\
\text { that I expected. }\end{array}$ & $0.842(.158)$ \\
\hline & $\begin{array}{l}\text { I'm concerned that this product would cause me damage } \\
\text { for not buying the right product. }\end{array}$ & $0.689(.135)$ \\
\hline & $\begin{array}{l}\text { I think that most probably this product would cause my } \\
\text { financial loss. }\end{array}$ & 0.547 \\
\hline \multirow[t]{3}{*}{ Trialability } & I would have a trial of this product before adoption. & $0.604(.115)$ \\
\hline & I would have a proper trial of this product before I buy. & $0.869(.116)$ \\
\hline & $\begin{array}{l}\text { I want to have a trial of this product to learn various } \\
\text { applications before I buy. }\end{array}$ & 0.757 \\
\hline \multirow[t]{3}{*}{ Perceived Quality } & This product would have a good quality. & $0.888(.067)$ \\
\hline & This product would have an excellent quality. & $0.917(.066)$ \\
\hline & This product's quality would be trustworthy. & 0.842 \\
\hline \multirow[t]{3}{*}{ Purchase Intention } & I would have an intention to buy it in the future. & $0.788(.091)$ \\
\hline & I would have a probability of buying this product. & $0.854(.084)$ \\
\hline & I would have a plan to buy this product. & 0.812 \\
\hline \multicolumn{3}{|c|}{$\chi^{2}=301.649$, d.f. $=160, p=.000 ; R M R=.147, G F I=.850, C F I=.938, R M S E A=.072$} \\
\hline
\end{tabular}


values greater than 1.00 . The largest explained percentage of variance was $27.5 \%$, and no single factors caused most the variance, which assured of not having a severe common method bias. Additionally, we conducted a test with an unmeasured latent methods factor (LCMVF). We specified a model that included the constructs of our conceptual model and on additional method. Both of two models do not show any significant difference $\left(\Delta \chi^{2}=40.1\right.$; d.f. $\left.=20\right)$. The factor loadings show the same directions and remained significant. Thus, two of statistical test results indicate that our data set does not have common methods bias.

\subsection{Results}

The results showed a good model fit to our normalized data $\left(\chi^{2}=341.906\right.$, d.f. $=163, p=.000$; $\mathrm{GFI}=.836 ; \mathrm{CFI}=.922 ; \mathrm{RMR}=.301 ; \mathrm{RMSEA}=$ .080 ). The result shown in Table 3 provided strong support for our model. As we expected, perceived quality positively related to purchase intention $(\gamma=.260$ (.099), $\mathrm{p}<.01)$. Moreover, trialability have positive impact on perceived quality $(\gamma=.329(.094) ; \mathrm{p}<.01)$.However, perceived usefulness and perceived risk is not significantly related to the perceived quality. Therefore, hypotheses 1 and 4 are supported.

In addition, we validate the mediating roles of perceive quality. We conducted two tests: a chi-square difference test and the Sobel test (Sobel 1982) following Hoyle and Smith (1994). It shows that perceived quality mediates $70.5 \%$ of the effects of the trialability, and not for the perceived usefulness and perceived risk and the results of and chi-square difference and Sobel test were also significant. It indicates that perceived quality fully mediated the relationship between triablility and purchase intention.

\section{Discussion and Conclusion}

\subsection{Summary and Conclusions}

New innovative product is fast diffusing among

〈Table 3〉 Summary of Result: Hypothesis Testing of Main Effect

\begin{tabular}{lcc}
\hline \multicolumn{1}{c}{ Structure Paths } & $\begin{array}{c}\text { Standardized } \\
\text { (S.E.) }\end{array}$ & t-value \\
\hline Perceived Quality $\rightarrow$ Purchase Intention & $.260(.099)$ & $3.054^{* * *}$ \\
Perceive Usefulness $\rightarrow$ Perceived Quality & $.085(.071)$ & .922 \\
Perceive Risk $\rightarrow$ Perceived Quality & $-.099(.098)$ & -.1 .082 \\
Trialability $\rightarrow$ Perceived Quality & $.329(.094)$ & $3.524^{* * *}$ \\
\hline Overall Model Fit & \\
$\chi^{2}=341.906$, d.f. $=163, \mathrm{p}=.000 ;$ GFI $=.836:$ CFI $=.922:$ RMR $=.301:$ RMSEA $=.080$ & \\
\hline
\end{tabular}


users and is expected to reach the majority of Chinese consumers in the near future. Therefore the study on the diffusion adoption process of new product appears to be especially important. As most adoption models such as TAM, offer little insight into the adoption process of a new product. The quality perception of a product is now included because it is very important in the marketing field, although it is given very little attention in the MIS and Communication Field.

We developed a new model to estimate the new technology adoption model by exploring the antecedents of perceived quality based on reviewing the existing literature. Our results confirm that perceived quality is positively related to purchase intention. We also find that trialability have a positive impact on perceived quality.

Our result suggests that trialability is an important adoption factors. For Chinese, the trialability of the product is the most important factor in adoption of new product. As mentioned before the Chinese culture does not favor uncertainties and changes (Mao and Palvia 2006) it seems that they would commit to a change or to a new technology only if they try a product on a limited base. Technology Adoption has been applied in the developed world (Boudreau, gefen and Straub 2001: Legris, Ingham and Collerette 2003). However, until recently, little work has been done on the application of new product adoption to developing counties. Even though China has developed fast, it is still in the process of developing.
This study contributes to the existing literature on new products adoption process for the following reason. In contrast to previous studies that investigate how the TAM model affects products in the industrial engineering or MIS field, this study underlines the role of perceived quality, which is an important variable in the marketing field. We suggest a new model of innovation adoption model by focusing on the role of perceived quality. Moreover, we investigate the inside mechanism of the model whereas previous studies of TAM mainly concern the direct effect of the antecedents of adoption intention. We also focus the consumers' perception of using the innovations rather than perception of the innovation. Since different adopters might perceive primary characteristic in different ways, their actual behaviors might differ depending on the perception of the innovation (Moore and Benbasat 1991).

To sum up, we conclude that a product's perceived quality plays an important role in adoption intention of new product. And what makes Chinese customers perceive product's quality good is a trialability of a product. This suggests that when market managers intend to launch products in China, they need to craft a proper strategy based on the market system of the consumer especially understanding the critical factor for specific customer. Chinese are more interested in purchasing a product with free trial and free experiential period, therefore, suggesting an advertising highlighting the trialability of a 
product is possible in China.

\subsection{Limitation and Further Research}

As in all research, there are some limitations that should be considered. First, the variables including perceived usefulness, perceived risk, and perceived quality do not actually measure consumers' perception rather than are answered based on their expectation. This is the innate problem of the previous TAM model. Therefore, the concept of the variables in the model was quoted without any change. Future study should be done by measuring the customer's actual perception with a product.

Second, the smartphone was used as the new target product. Since, there will most likely be some difference regarding the type of product. Other product will be used a new product to generalize the result in the future research.

Third, we only use a three variable such as perceived usefulness, perceived risk and trialability to influence the adoption intention. The variables such as perceived ease of use, compatibility, observability and perceived fun could be another factors for adoption intention in the future research(Rogers 2003: Davis 1989). Fourth, it would be worthwhile to compare the adoption behavior between two different countries such as the eastern and western countries.

〈논문 접수일: 2012. 03. 21〉

〈1차 수정일: 2012, 04, 16〉

〈게재 확정일: 2012. 04. 18〉

\section{References}

Aaker, David A.(1991), Managing Brand Equity. New York: The Free Press.

Aaker, D.A. and Keller, K.A. (1990), "Consumer Evaluations of Brand Extension," Journal of Marketing. 54(1), 27-41.

Adams, Dennis A., R. Ryan Nelson, and Peter A. Todd(1992), "Perceived Usefulness, Ease of Use, and Usage of Information Technology: A replication," MIS quarterly, 16 (2), Jun., 227-247.

Bagozzi, R.P. (2007), “The Legacy of the Technology Acceptance Model and a Proposal for a Paradigm Shift," Journal of the Association for Information Systems, 8(4), 243-54.

Bauer, R. A. (1960), "Consumer Behavior as Risk Taking," Dynamic marketing for a changing world. 398 .

Boisvert, A. and Ashill, N.J. (2011), "How Brand Innovativeness and Quality Impact Attitude Toward New Service Line Extensions. The Moderating Role of Consumer Involvement," Journal of Services Marketing, 25(7). 517527.

Boudreau, M. C., Gefen, D., and Straub, D. W. (2001). Validation in Information Systems Research: A State-of-the-art Assessment," MIS Quarterly, 25(1), 1-16.

Boulding, W., Ajay K., Richard S., and Valarie, A.Z. (1993), “A Dynamic Process Model 
of Service Quality: From Expectations to Behavioral Intentions," Journal of Marketing Research, 30. 7-27.

Chang, H.H. and Chen, S.W. (2008), "The Impact of Online Store Environment Cues on Purchase Intention - Trust and Perceived Risk as a Mediator," Online Information Review, 32(6). 818-841.

Chau, P.Y.K., and Ho, C.K.Y. (2008), "Developing Consumer-Based Service Brand Equity Via the Internet: The Role of Personalization and Trialability," Journal of Organizational Computing and Electronic Commerce, 18(3). 197-223.

Childers, T.L., Carr, C.L., Peck, J., and Carson, S. (2001), "Hedonic and Utilitarian Motivations for Online Retail Shopping Behavior," Journal of Retailing, 77(4), 511-35.

Clark, C. Robert,Ulrich Doraszelski, and Michaela Draganska(2009), "The Effect of Advertising on Brand Awareness and Perceived Quality: An Empirical Investigation Using Panel Data," Quantitative Marketing and Economics, 7(2), 207-236.

Cronin, J.J.Jr. and Taylor, S.A. (1992), "Measuring Service Quality. A Reexamination and Extension," Journal of Marketing, 56 (3). 55-68.

Davis, Fred D. (1989), "Perceived Usefulness, Perceived Ease of Use, and User Acceptance of Information Technology," MIS Quarterly, 13(3). 319-340.

Davis, Fred D. (1993), "User Acceptance of
Information Technology: System Characteristics, User Perceptions and Behavioral Impacts," International Journal of ManMachine Studies, 38(3), 475-487.

Dubey, P. and Wu, C. (2002), "Less Competition Induces More Product Innovation," Economics letters, 74(3). 309-312.

Eng,Teck-Yong and giulia Quaia(2009), "Strategies for Improving New Product Adoption in Uncertain Environments: A Selective Review of the Literature," Industrial Marketing Management, 38(3), April, 275282.

Featherman, Mauricio S., and Paul A Pavloub (2003), "Predicting E-Services Adoption: A Perceived Risk Facets Perspective," International Journal of Human-Computer Studies, 59(4), 451-474.

Fishbein, M. and Ajzen, I. (1975), Belief, Attitude, Intention, and Behavior: An Introduction to Theory and Research, AddisonWesley, Reading, MA.

Fishman, A. and Rob, R. (2002), "Product Innovations and Quality-Adjusted Prices," Economics Letters, 77(3). 393-398.

Fornell, C.D. and Larcker, F. (1981), "Evaluating structural equation models with unobservable variables and measurement errors," Journal of Marketing Research, Vol, 18, pp. 39-50.

Goldsmith, R.E., and Hofacker, C.F. (1991), "Mea- suring Consumer Innovativeness," Journal of the Academy of Marketing 
Science, 19(3). 209-221.

Gustafsson, A., Johnson, M.D., and Roos, I. (2005), "The Effects of Customer Satisfaction, Relationship Commitment Dimensions, and Triggers on Customer Retention," Journal of Marketing, 69. 210-218.

Hair, J.F., Black, W.C., Babin, B.J., Anderson, R.E. and Tatham, R.L. (2006), Multivariate Data Analysis. 6th ed., PrenticeHall, Englewood Cliffs, NJ.

Ho, Daniel, Graeme Newell and Anthony Walker, (2005), "The Importance of Property-Specific Attributes in Assessing CBD Office Building Quality," Journal of Property Investment \& Finance, 23(5), 424-444.

Holbrook, M.B. and Corfman, K.P. (1985), "Quality and Value in the Consumption Experience. Phaedrus rides again," Perceived quality, 31. 31-57.

Hoyle R.H. and Smith G.T.(1994), "Formulating Clinical Research Hypotheses as Structural Equation Models," Journal of Consumer Clinique Psychology, 62, 429-440.

iResearch (2011), iResearch China Mobile Netizen Internet Phone Acts Research Report 2011. available at: www.spforum.net/files/info161943-777419.PDF (accessed April 15, 2011). Jacoby, J. \& Kaplan, L.B. (1972), "The Components of Perceived Risk," Advances in consumer research, 3(3). 382-383.

Karahanna, E., Straub, D.W., and Chervany, N.L. (1999), "Information Technology Adoption Across Time. A Cross-Sectional Com- parison of Pre-Adoption and Post-Adoption Beliefs," MIS Quarterly, 23(2). 183-213.

Kotler, P. (1994), Marketing Management. Analysis, Planning, Implementation, and Control. 8th Ed, Prentice Hall, Englewood Cliffs, NJ

Koufteros, X. A., Vonderembse, M.A., and Doll, W.J. (2002), “Integrated Product Development Practices and Competitive Capabilities. The Effects of Uncertainty, Equivocality, and Platform Strategy," Journal of Operations Management, 20(4), 331-355.

Lin, D., Narashihan, L and He. J.(2011), "Understanding China's Digital Consumers," www. mackinsyquaterly.com, 4.

Liu, Y. and Li, H.(2009), "Mobile internet diffusion in China: An Empirical Study," Industrial Management \& Data Systems, 110(3), 309-324.

Ladhari,Riadh, Nizar Souiden and Ines Ladhari (2011), "Determinants of Loyalty and Recommendation: The Role of Perceived Service Quality, Emotional Satisfaction and Image," Journal of Financial Services Marketing, 16, 111-124.

Legris, P., J. Ingham, and P. Collerette(2003), "Why Do People Use Information Technology? A Critical Review of the Technology Acceptance Model," Information \& Management, 40(3), 191-204,

Lu ,J., L. Z. Wang, and C. S. Yu(2007), "Is TAM for Wireless Mobile Data Services Applicable in China? A Survey Report from 
Zhejiang, China," International Journal of Mobile Communications, 5(1), 11-31.

Lu, J., Yao, J.E., and Yu, C.S. (2005), "Personal Innovativeness, Social Influences and Adoption of Wireless Internet Services Via Mobile Technology," Journal of Strategic Information Systems, 14, 245-268.

Mao, E., and Palvia, P. C. (2006), "Testing an Extended Model of IT Acceptance in the Chinese Cultural Context," The data base for advances in Information Systems, 37 (2/3), 20-32.

Moore, G.C. and Benbasat, I. (1991), "Development of an Instrument to Measure the Perceptions of Adopting an Information Technology Innovation," Information Systems Research, 2(3), 192-222.

Nunnally, Jum C. (1978). Psychometric Theory. 2nd ed. New York: McGraw-Hill Book Company.

Nysveen, H., Pedersen, P.E., and Helge, T. (2005), "Explaining Intention to Use Mobile Chat Services: Moderating Effects of Gender," Journal of Consumer Marketing, 22 (4/5), 247-256.

Pagani, M. (2004), "Determinants of Adoption of Third Generation Mobile Multimedia Services," Journal of Interactive Marketing, 18(3), 46-59.

Parasuraman, R., Mouloua, M., and Molloy, R. (1996), "Effects of Adaptive Task Allocation on Monitoring of Automated Systems," Human Factors, 38, 665-679.
Park, J.H. (1999), "An Empirical Study on the Hotel Guests' Perceived Risk Toward Hotel Service," Journal of Tourism and Leisure, 11(1), 27-41.

Park, Y.K. and Kim, C.W. (2002), “A Study on Factors Affecting PB(Private Brand) Products Preference," Journal of Global Academy of Marketing Science, 9, 1-13.

Podsakoff, P. M., MacKenzie, S. B., JeongYeon, L., and Podsakoff, N. P. (2003), "Common Method Biases in Behavioral Research: A Critical Review of the Literature and Recommended Remedies," Journal of Applied Psychology, 88(5), 879.

Rogers, E.M. (1983). Diffusion of Innovations, Free Press. New York, NY.

Rogers, E.M. (1995). Diffusion of Innovations,

Free Press. New York, NY.

Rogers, E.M. (2003). Diffusion of Innovations, 5th ed., Free Press, New York, NY.

Roselius, T. (1971), "Consumer Rankings of Risk Reduction Methods," The Journal of Marketing, 35(1), 56-61.

Sobel, M. E. (1982), Asymptotic Confidence Intervals for Indirect Effects in Structural Equation Models. in S. Leinhardt (ed.) Sociological Methodology, San Francisco, Jossey-Bass, 290-313

Sweeney, J.C., Soutar, G.N., and Jonshon, L.W. (1999), "The Role of Perceived Risk in the Quality-Value Relationship: A Study in a Retail Environment," Journal of Retailing, 75. 77-105. 
Tung, F.C., Chang, S.C., and Chou, C.M. (2008), "An Extension of Trust and TAM model with IDT in the Adoption of the Elec- tronic Logistics Information System in HIS in the Medical Industry," International Journal of Medical Informatics, 77 (5), 324- 335 .

Washburn,J. H., B. D. Till, and R. Priluck (2000), "Co-branding: Brand Equity and Trial Effects," Journal of Consumer Marketing, 17(7), 591-604.

Yang, Z., Cai, S., Zhou, Z., and Zhou, N. (2005), "Development and Validation of an Instrument to Measure User Perceived Service Quality of Information Presenting Web Portals," Information \& Management, $42,575-589$.
Zaichkowsky, Judith Lynne (1985), "Measuring the Involvement Construct," Journal of Consumer Research, 12, 341-352.

Zeithaml, Valarie A. (1987), “Defining and Relating Price, Perceived Quality, and Perceived Value,"Working Paper No. 87-101, Marketing Science Institute, Cambridge, MA 02138.

Zeithaml, V. A. (1988), “Consumer Perceptions of Price, Quality, and Value. A MeansEnd Model and Synthesis of Evidence," Journal of Marketing, 52(3). 2-22.

Zikmund, W. and J. Scott(1973), "A Multivariate Analysis of Perceived Risk, Self Confidence and Information Sources, in: S. Ward, P. Wright (Eds.). Advances in Consumer Research, 1, Association for Consumer Research, Urbana, IL, 406-416. 